\title{
A Restorative Response to Victims in Proceedings before the International Criminal Court: Reality or Chimaera?
}

\author{
Alessandra Cuppini \\ Associate Lecturer, The Open University, Milton Keynes, UK \\ drcuppinialessandra@gmail.com
}

\begin{abstract}
The integration of the framework of victims' participation into the legal proceeding of the International Criminal Court (ICC) has been seen as a transformation of the ICC process beyond narrow retribution to better accommodate restorative justice (RJ) values and practices. However, there is little research into whether, or how the ICC metes out RJ. This article argues that RJ principles brought within ICC emphasise the growing importance that victims' participation in proceedings plays in achieving justice for victims. It then examines how the ICC process aligns to the key elements of RJ practice, namely victim-offender meeting; offender's acknowledgement of responsibility and apology; collaborative conflict-resolution approach; victims' healing and reconciliation; symbolic reparation and material restitution. This article demonstrates that these elements, developed to address ordinary juvenile criminality, are not structured to operate in the particular context of the ICC, characterised by grave harm caused to victims and communities by mass atrocity.
\end{abstract}

\section{Keywords}

victim's participation - international criminal court - restorative justice 
Due to the growing recognition of the impact of mass crimes on victims and communities, victims' right to, and need for, justice have become important considerations in international criminal justice. A significant amount of literature has focused on highlighting the negative effects of widespread and systematic violence, ${ }^{1}$ which affects victims and communities by attacking the social values and safety of those communities and determining, consequently, a general social collapse. ${ }^{2}$ The limited representation of victims of mass violence, whose perceptions and needs were frequently ignored, presumed, or misunderstood, ${ }^{3}$ has urged for positioning victims' participation in international criminal proceedings, wherein they bring a unique perspective on the factual and cultural elements vital to assist in the comprehension of the context of violence. ${ }^{4}$ As such, the challenge of addressing the needs for justice of victims of international crimes has been subject to increasing normative development in recent years. ${ }^{5}$ This can be evidenced by the incorporation of a regime of victims' participation ${ }^{6}$ and reparation ${ }^{7}$ for victims in the Statute of the International Criminal Court (ICC). Much of the discourse around the new positioning of victims as 'active participants' within the ICC proceedings

See, e.g., Kristen Hagen and Sophie Yohani, 'The Nature and Psychosocial Consequences of War Rape for Individuals and Communities', 2 International Journal of Psychological Studies (2010) 14-25; Julie Mertus, 'Shouting from the Bottom of the Well: The Impact of International Trials for Wartime Rape on Women's Agency', 6 International Feminist Journal of Politics (2004) 110-128; Nicola Henry, 'The Impossibility of Bearing Witness: Wartime Rape and the Promise of Justice', 16 Violence Against Women (2010) 1098-1119; Inger Skjelsbæk, 'Victim and Survivor: Narrated Social Identities of Women Who Experienced Rape During the War in Bosnia-Herzegovina', 16 Feminism \& Psychology (2006) 373-403. Nathalie E.J. Dijkman, Catrien Bijleveld and Philip Verwimp, 'Sexual Violence in Burundi: Victims, Perpetrators, and the Role of Conflict', Households in Conflict Network Working Paper (2014), p. 33.

Fiona McKay, Universal Jurisdiction in Europe: Criminal Prosecutions in Europe since 1990 for War Crimes, Crimes Against Humanity, Torture \& Genocide (REDress 1999), p. 15. See also Women's Caucus for Gender Justice, Recommendations and Commentary for August 1997 PrepCom on the Establishment of an International Criminal Court, United Nations Headquarters (1997) 29, http://iccnow.org/documents/WomensCRecomm.pdf, accessed 15 July 2020; Yael Danieli, 'Victims: Essential Voices at the Court', The Bulletin of the Victims' Rights Working Group (2004) 6, http://www.vrwg.org/ACCESS/ENGo1.pdf, accessed 15 July $2 \mathrm{O} 2 \mathrm{O}$. Mariana Pena and Gaelle Carayon, 'Is the ICC Making the Most of Victim Participation?' 7 International Journal of Transitional Justice (2013) 523-527.

5 See Eccc, Internal Rules, Rule 23; STL, Statute, Article 17.

6 ICC, Rome Statute, Article 68(3).

7 Ibid., Art. 75; ICC, RPE, Rules 94-99. 
engages with the claim that this new victim-oriented framework aligns the ICC's justice approach to the restorative justice (RJ) paradigm. ${ }^{8}$ According to Findlay, the very legitimacy of international criminal justice depends upon a 'victim constituency' being centrally recognised, meaning that, ultimately, criminal justice has no choice but to embrace restorative practices. ${ }^{9}$ However, there is no consensus on this issue. Experts, including McGonigle Leyh, have stated that the victim's participation scheme at the ICC is not the same as an RJ process, and that victims cannot, and do not, experience it as such. ${ }^{10}$ Moffett argued that, while the Court can be more victim-orientated with the inclusion of provisions for victims' participation, the ICC should maintain its core retributive goal and remain focused on prosecuting and punishing perpetrators. ${ }^{11}$ Similarly, Vasiliev argued that the ICC should free itself from the 'restorative complex'. ${ }^{\prime 2}$

This article, therefore, engages with the vexata quaestio of whether and to what extent the ICC system of justice can be labelled as a restorative mechanism, aiming at exposing the limitations that the RJ paradigm faces when entering the international criminal justice arena. For this analysis, Braithwaite and Strang's definition is utilised for its prioritisation of a conception of RJ involving a commitment to both restorative principles and restorative processes, the latter being conceived as a system of practices and outcomes. ${ }^{13}$ This article argues that, to some extent, the ICC embraces RJ principles, such as

Mark J. Findlay and Ralph Henham, Transforming International Criminal Justice: Retributive and Restorative Justice in the Trial Process (Willan Publishing, Cullompton, 2005), p. 275; Silvia A. Fernández de Gurmendi and Håkan Friman, 'The Rules of Procedure and Evidence of the International Criminal Court', 3 Yearbook of International Humanitarian Law (2000) 289-336 p. 312; Jo-Anne Wemmers, 'Victims' Rights and the International Criminal Court: Perceptions within the Court Regarding the Victims' Right to Participate', 23 Leiden Journal of International Law (2010) 629-643, p. 630; Nancy A. Combs, Guilty Pleas in International Criminal Law: Constructing a Restorative Justice Approach (Stanford University Press, Stanford, 2007), p. 141. Mark Findlay, 'Activating a Victim Constituency in International Criminal Justice', 3 International Journal of Transnational Justice (2009) 183-206, p. 203.

Brianne McGonigle Leyh, Procedural Justice? Victim Participation in International Criminal Proceedings (Intersentia, Mortsel, 2011), p. 358.

Luke Moffett, 'Meaningful and Effective? Considering Victims' Interests Through Participation at the International Criminal Court', 26 Criminal Law Forum (2015) 255-289. Sergey Vasiliev, 'Victim Participation Revisited: What the ICc Is Learning About Itself', in Carsten Stahn (ed.), The Law and Practice of the International Criminal Court (Oxford University Press, Oxford, 2015), p. 64.

13 John Braithwaite and Heather Strang, 'Introduction: Restorative Justice and Civil Society', in John Braithwaite and Heather Strang (Eds), Restorative Justice and Civil Society (Cambridge University Press, Cambridge, 2001), p. 2. 
hearing the voices of victims, restoring lost dignity, healing and reconciling communities, but proceedings before the ICC are not the appropriate venue to run restorative practices. Even though the Rome Statute includes an element of restorative practice, as it previews the possibility of participation and reparation for victims, the ICC is not structured to adhere to the typical practices of RJ. To explore the ICC's alignment to the practices of RJ, this article analyses the five basic elements of restorative practices identified by Van Ness and Heetderks Strong: victim-offender meeting; offender's acknowledgement of responsibility and apology; collaborative conflict-resolution approach; healing and reconciliation of victims; symbolic reparation and material restitution. ${ }^{14}$ These elements, which serve as framing devices to depict the restorative process from its beginning through to its outcome, are evaluated against the context of the ICC, based on (1) their responsiveness to the socio-political context and nature of international crimes, which involve acts of mass violence and mass victimisation; and (2) their applicability to criminal justice processes, focused on providing accountability for such serious crimes. First, the mass violence nature of the atrocities that come under the jurisdiction of the ICC and the following general social collapse in post-conflict societies ${ }^{15}$ pose a great challenge to the restorative substantive practices, which are structured to address low-level crime within criminal justice systems of Westerner democratic societies. The distinct differences between acts committed in the context of ordinary crime and crimes of mass violence in a conflict situation serve to highlight the limitations of the portability of restorative practices, intended as a mechanism for participation, healing, reparation and reconciliation, into the internal rationale of the criminal process at the ICC, oriented towards accountability. The application of restorative practices within the ICC, requiring them to operate in a socio-political context quite different from their original one, eventually stretches the five elements of the restorative paradigm beyond their original framework. Second, in line with the challenges attached to the applicability of RJ practices to criminal justice processes, criticisms hold that such practices are 'a diversion from court prosecution; actions taken in parallel with court decisions, and meetings between victims and offenders at any stage of

14 Daniel Van Ness and Karen Heetderks Strong, Restoring Justice: An Introduction to Restorative Justice (Anderson Publishing, Waltham, MA, 1997); Daniel Van Ness, 'The Shape of Things to Come: A Framework for Thinking About a Restorative Justice System', in Elmar G. M. Weitekamp and Hans-Jürgen Kerner (eds), Restorative Justice: Theoretical Foundations (Willan Publishing, Cullompton, 2002), pp. 1-20.

Dijkman, Bijleveld and Verwimp, supra note 2, p. 33 . 
the criminal process. ${ }^{\prime 16}$ This article seeks to illustrate that the limits of routing $\mathrm{RJ}$ practices through the vehicle of international criminal justice are the result of the attempt to bend the criminal process at the ICC, where the retributive system's elements gain preponderance, to suit a restorative dimension.

This article proceeds as follows. The second section locates ICC's restorative turn in relation to the integration of victims into its proceedings and their contribution to the processes of truth and justice. The following section provides an overview of the central tenets of RJ practices as applied to common crimes in criminal justice systems of peacetime societies. It identifies and provides a full understanding of the five elements around which restorative processes are structured. Section four focuses on the implementation of restorative practices in cases involving gross violations of human rights under the jurisdiction of the ICC. It discusses the extent to which the restorative practices are structured to effectively work within the framework of the ICC. It does so by framing the analysis around the key features of the RJ practice into five subsections. The subsections are devoted to analysing how far the process before the ICC aligns to each of the five elements of restorative practices, namely victim-offender meeting; offender's acknowledgement of responsibility and apology; collaborative conflict-resolution approach; healing and reconciliation of victims; and symbolic reparation. The last section introduces a reflection on the challenges encountered by elements of RJ practice in the context of the ICC's justice method. It suggests that the ICC can make an important contribution to achieving justice for victims and redressing their harm; however, it would be short-sighted to put the restorative label on this international criminal justice institution.

Gross violations of human rights have been, and continue to be, perpetrated in several armed conflicts as well as in peacetime. While it might have been expected that the extensive nature, seriousness and recurrence of the atrocities committed would have triggered the operation of an effective scheme of victims' participatory rights as a response to those violations, the reality seems to have been the reverse. Provisions of the earliest institutions of international criminal justice, namely the International Criminal Tribunal for the former

16 Kathleen Daly, South Australia Juvenile Justice (SAJJ) Research on Conferencing, Technical Report No. 2: Research Instruments in Year 2 (1999) and Background Notes (Griffith University, Brisbane, 2001), p. 5. See also Ashworth, supra note 48, pp. 281-282. 
Yugoslavia (ICTY) and the International Criminal Tribunal for Rwanda (ICTR), do not confer upon victims any independent standing in criminal proceedings. Victims could participate in proceedings only as witnesses, since their participation was ruled by the norms governing witnesses' testimony. ${ }^{17}$ In practice, the actual possibility for a victim to be able to tell her/his story at trial-stage relied on either one of the parties (prosecutor or defence) summoning her/ him and the chamber approving the summoning or the chamber itself calling her/him to testify. ${ }^{18}$ The mandates of the ICTY and ICTR are the main reason explaining the marginal role of victims before these tribunals. The concept informing those systems is punitive, since the UN Security Council resolutions setting up the ICTY and ICTR assert that they have been established 'for the sole purpose of prosecuting persons responsible for serious violations of humanitarian law.' 19

The drafters of the Statute and the RPE of the ICC were fully aware of the incredible opportunity to fill the gap left by the ICTY and ICTR, which failed to provide for the active participation of victims of gross violations of human rights during their proceedings. The acknowledgement that 'millions of children, women, and men have been victims of unimaginable atrocities ${ }^{20}$ empha- $^{-}$ sises the importance of understanding the devastating effect that crimes can have on victims and recognises the growing importance that participation and reparations play in providing them with more meaningful and tangible justice. ${ }^{21}$ The ICc Statute has set an important standard in international criminal law, since it elevates victims to the status of participants in their own right. Article 68(3) of the ICC Statute provides that

Where the personal interests of the victims are affected, the Court shall permit their views and concerns to be presented and considered at stages of the proceedings determined to be appropriate by the Court and in a manner which is not prejudicial to or inconsistent with the rights of the accused and a fair and impartial trial (...)

17 ICTY, RPE, Rule 9o; ICTR, RPE, Rule 9o.

18 Mikaela Heikkilä, International Criminal Tribunals and Victims of Crime: A Study of the Status of Victims before International Criminal Tribunals and of Factors Affecting This Status (Institute for Human Rights Åbo Akademi University, Turku, 2004), pp. 74-75.

19 UNSC, Resolution 827 (S/RES/827); UNSC, Resolution 955 (S/RES/955).

20 ICC, Rome Statute, Preamble.

$21 \quad$ Sam Garkawe, 'Victims and the International Court: Three Major Issues', 3 International Criminal Law Review (2003) 676. See also Assembly of States Parties, Report of the Court on the Strategy in Relation to Victims (ICC-ASP/8/45), paras 2-3. 
This innovative victim-oriented provision suggests that the ICC holds an aspiration beyond the traditional punitive function. The wording of Article 68(3) points out that the core scope of the active role granted to victims is not simply correlated to the goal of punishing who commits crimes. Rather, the opportunity for victims to have their voices heard permits them to represent and pursue their interests. ${ }^{22}$ This provision of the Rome Statute expands the notion of 'interest of justice' to be more attuned to the idea of 'justice for victims', ${ }^{23}$ which has been recognised as the raison dêtre of the ICc. ${ }^{24}$ The redefinition of 'interest of justice' urges the ICC not only to ensure that victims are granted some form of support and a role in proceedings which affect their interests, but also to fully restore the harm they have suffered and contribute to the process of reconciliation of conflict-affected communities, by redressing the causes of victimisation. ${ }^{25}$

The view that the integration of victims as active participants within the ICC proceedings can contribute to reconciliation, restoration and justice for victims has been developed into a narrative claiming that ICC operates as a mechanism of RJ. Several commentators have asserted that the ICC does not stand only for criminal accountability, but also for 'social welfare and $\mathrm{RJ}^{26}{ }^{26}$ Wemmers ${ }^{27}$ and Combs $^{28}$ suggested the icc marks something of a shift away

Theo Van Boven, 'Victims' Rights and Interests in the International Criminal Court, in José Doria, Hans-Peter Gasser, and Mahmoud Cherif Bassiouni (eds), The Legal Regime of the International Criminal Court: Essays in Honour of Professor Igor Blishchenko (1930-200o) (Martinus Nijhoff Publishers, Leiden, 2009), p. 902.

23 Luke Moffett, Justice for victims before the International Criminal Court (Routledge, Oxon, 2014), pp. 86-87; Claire Garbett, 'From Passive Objects to Active Agents: A Comparative Study of Conceptions of Victim Identities at the ICTY and ICC', 15 Journal of Human Rights (2016) 40-59, p. 51.

Opening Speech by French Justice Minister Elisabeth Guigou at the International Meeting on 'Access of Victims to the International Criminal Court', quoted in Dominic McGoldrick, Peter Rowe and Eric Donnelly (eds), The Permanent International Criminal Court: Legal and Policy Issues (Hart Publishing, Portland, 2004), p. 322.

25 Moffett, supra note 24, p. 102.

26 Emily Haslam, 'Victim Participation at the International Criminal Court: A Triumph of Hope Over Experience?' in McGoldrick, Rowe and Donnelly supra note 22, p. 315. See also Jenia Iontcheva Turner, 'Legal Ethics in International Criminal Defense', 10 Chicago Journal of International Law (2010) 685-746, pp. 695-696; Navanethem Pillay, 'Equal Justice for Women: A Personal Journey', 5o Arizona Law Review (2008) 657-671; Gilbert Bitti and Håkan Friman, 'Participation of Victims in the Proceedings', in Roy S Lee (ed.), The International Criminal Court: Elements of Crimes and Rules of Procedure and Evidence (Transnational Publishers, New York, NY, 20o1), pp. 456-457.

$27 \quad$ Wemmers, supra note 8.

28 Combs, supra note 8. 
from purely retributive international criminal justice, towards a more expansive model that incorporates elements of RJ. By the same token, Funk and Guhr advanced that enabling victims to participate in international criminal justice indicates a broader construction of justice than retribution and deterrence, towards a more reparative approach that seeks to restore victims. ${ }^{29}$

These commentaries suggesting that the ICC has turned towards a restorative form of justice are based on the intersection between the concept of 'justice for victims' and the RJ approach towards victim constituency. RJ works from the premise that crime is an 'individual, relational and social harm'30 done to victims and communities, causing divisions in the social fabric. ${ }^{31}$ With a view to address these divisions, the RJ is informed by a set of values and principles, ${ }^{32}$ including the healing of victims and society; ${ }^{33}$ amends made by the offender; ${ }^{34}$ reconciliation of parties and community; ${ }^{35}$ reparation of the harm caused to victims; ${ }^{36}$ and active participation of parties in the process. ${ }^{37}$ Concerning the role of victim-participant in particular, primary concerns of $\mathrm{RJ}$ are giving voice to victims, healing them through positive engagement in the process and repairing the harm they suffered. ${ }^{38}$

T. Markus Funk, Victims' Rights and Advocacy at the International Criminal Court (Oxford University Press, Oxford, 2010), p. 4; Alexandra H. Guhr, 'Victim Participation During the Pre-Trial Stage at the International Criminal Court', 8 International Criminal Law Review (2008) 109 Victim Participation During the Pre-Trial Stage at the International Criminal Court', 8 International Criminal Law Review (2008) 109-140, pp. 109-110.

Lode Walgrave, 'Restorative Justice: An Alternative for Responding to Crime?', in Shlomo Giora Shoham, Ori Beck and Martin Kett (eds), International Handbook of Penology and Criminal Justice (Crc Press, Boca Raton, FL, 2008), p. 621. James Coben and Penelope Harley, 'International Conversations About Restorative Justice, Mediation and The Practice of Law', 25 Hamline Journal of Public Law \& Policy (2004) 235-334, p. 240; Carrie J. Niebur Eisnaugle 'An International “Truth Commission”: Utilizing Restorative Justice as an Alternative to Retribution', 36 Vanderbilt Journal of Transnational Law (2003) 209-242, p. 211.

Lawrence Sherman, 'Two Protestant Ethics and the Spirit of Restoration', in Braithwaite and Strang, supra note 13, p. 55 .

Daniel Van Ness, 'The Shape of Things to Come: A Framework for Thinking About a Restorative Justice System', in Elmar G.M. Weitekamp and Hans-Jürgen Kerner (eds), Restorative Justice: Theoretical Foundations (Willan Publishing, Cullompton, 2002), p. 4. Howard Zehr, Changing Lenses: A New Focus for Crime and Justice (Herald Press, Scottdale, PA, 1990), pp. 200-203; Chris Cunneen, 'Reparations and Restorative Justice: Responding to Gross Violations of Human Rights', in Braithwaite and Strang, supra note 13, p. 88.

Gordon Bazemore and Mara Schiff, 'Paradigm Muddle or Paradigm Paralysis? The Wide and Narrow Roads to Restorative Justice Reform (Or, A Little Confusion May Be a Good Thing)', 7 Contemporary Justice Review (2004) 37-57, p. 41.

$38 \quad$ Pena and Carayon, supra note 4. 
The inclusiveness of victims' constituency at the ICC seems to be consistent with the restorative model of justice, since it seeks to connect international criminal justice to the process of social reconciliation typical of the RJ paradigm. ${ }^{39}$ In the aftermath of mass atrocities, victims must not only cope with their individual suffering, but also participate in the process of social healing involving all those affected by the violence. ${ }^{40}$ The recovery of victims is, thus, intertwined to the restoration of the socio-political fabric, as reconciliation requires not only the healing of individuals, but also of society as a whole. ${ }^{41} \mathrm{In}$ this view, the right of victims to actively participate in proceedings at the ICC becomes an important factor in this healing process, ${ }^{42}$ as well as an indispensable element if post-conflict justice processes are to be 'capable of building the foundations for a strong transition through empowerment of those who were victimised during conflict. ${ }^{3} 3$

Along with the academic commentary suggesting that the ICC leans towards a restorative turn, the proposition that the ICC metes out RJ to victims through their participation in legal proceedings, was advanced by Judge Silvia Fernandez de Gurmendo, ${ }^{44}$ Judge Sang-Hyun Song ${ }^{45}$ and the Registrar. ${ }^{46}$

39 Carsten Stahn, 'International Criminal Justice and Reconciliation: Beyond the Retributive v. Restorative Divide', 36 FICHL Policy Brief Series (2015) 1-4, p. 3.

Mina Rauschenbach and Damien Scalia, 'Victims and International Criminal Justice: A Vexed Question?', 9o International Review of the Red Cross (2008) 441-459, p. 451.

$41 \quad$ Ibid., p. 453.

42 Assembly of States Parties, International Criminal Court, Report of the Court on the strategy in relation to victims (ICC-ASP/8/45), para. 2. See also Yael Danieli, 'Massive Trauma and the Healing Role of Reparative Justice,' in Carla Ferstman, Mariana Goetz and Alan Stephens (eds), Reparations for Victims of Genocide, Crimes against Humanity and War Crimes: Systems in Place and Systems in the Making (Martinus Nijhoff, Leiden, 20o9); Mariana Goetz, 'The International Criminal Court and Its Relevance to Affected Communities,' in Nicholas Waddell and Phil Clark (eds), Courting Conflict? Justice, Peace and the ICC in Africa (Royal African Society, London, 2008); Fiona McKay, Universal Jurisdiction in Europe: Criminal Prosecutions in Europe since 1990 for War Crimes, Crimes against Humanity, Torture and Genocide, https://redress.org/wp-content/uploads/2018/o1/ G.-June-1999-Universal-Jurisdiction-in-Europe.pdf, accessed 1o December 2020; Pena and Carayon, supra note 4.

43 Pena and Carayon, supra note 4, pp. 519, 518-535.

44 President Judge Silvia Fernandez de Gurmendo, International Criminal Court Today: Challenges and Opportunities, 9 June 2016, p. 4, www.icc-cpi.int/itemsDocuments/16oo6o9Helsinki-keynote-speech-ICC-President-Fernandez.pdf, accessed 10 December 2020. ICC Press Release, ICc President Tells World Parliamentary Conference "ICc brings retributive and restorative justice together with the prevention of future crimes", 11 December 2012.

46 Registrar Herman von Hebel, Remarks to the 15th session of the Assembly of States Parties, 21 November 2016, p. 11, asp.icc-cpi.int/iccdocs/asp_docs/ASP15/ASP15-Opening-StatementRegistrar-ENG.pdf, accessed 10 December 2020. 
The Report of the Court on the strategy in relation to victims (Strategy) affirmed that a key feature of the system established in the Rome Statute is the recognition that the ICC has not only a punitive, but also a restorative function, which reflects the growing importance that participation and reparations play in achieving justice for victims. ${ }^{47}$ In the following Court's Revised Strategy in Relation to Victims (Revised Strategy), the ICC emphasised the key role played by victims - as participants - before the Court and the importance of the Court's restorative function. ${ }^{48}$

The view that RJ can play an important role in dealing with gross violations of human rights at the judicial level, such as in criminal cases brought before the ICC, merits further scrutiny. The widely-held assumption that central principles of RJ have been increasingly invoked and utilised in the justice approach of the ICC involves theoretical claims based on the socio-political and philosophical background of $\mathrm{RJ}$, but it does not engage with the restorative process as it operates as a system of rules, practices and outcomes. ${ }^{49}$ It is, therefore, necessary to explore the structures of restorative substantive practices to provide an understanding of the restorative process as it operates from its beginnings through to its outcome.

A variety of programmes fall under umbrella term of $\mathrm{RJ}$ practices, which extends to victim-focused initiatives, such as victim compensation schemes, victim-offender mediation, crime repair crews, victim intervention programmes, family group conferencing, peace-making circles, sentencing circles, community reparative boards before which offenders appear, victim empathy classes for offenders, community-based support groups for crime-victims and community-based support groups for offenders. ${ }^{50}$ Due to this profusion

Assembly of States Parties, International Criminal Court, Report of the Court on the Strategy in Relation to Victims (ICC-ASP/8/45), para. 3 .

48 Assembly of States Parties, International Criminal Court, Court's Revised Strategy in Relation to Victims (ICC-ASP/11/38), para. 2. See also Assembly of States Parties, International Criminal Court, Report of the Court on the Implementation in 2013 of the Revised Strategy in Relation to Victims (ICC-ASP/12/41), paras 2, 28; Assembly of States Parties, International Criminal Court, Report of the Court on the Revised Strategy in Relation to Victims: Past, Present and Future (ICC-ASP $/ 11 / 40$ ), para. 34.

Claire Garbett, “And Focused Upon Victims' Needs": Towards an Assessment of the Victim-Friendly Principles of Restorative Justice Practice', 19(3) Contemporary Justice Review (2016) 307-324, p. 308.

$5^{\circ}$ James Dignan, Understanding Victims and Restorative Justice (Open University Press, Maidenhead, 2004), p. 2; M Heikkilä, supra note 18, p. 39. 
of practices falling under the rubric of restorative process, there is still contention among academics on its precise definition. ${ }^{51}$ The difficulty in defining $\mathrm{RJ}$ as a process can be attributed to the various elements involved in the restorative mechanisms and methods, which 'are given differing weights (...) reflecting different 'sensibilities' and cultures. ${ }^{52}$ Marshall has offered one of the most widely accepted definitions, ${ }^{53}$ which described RJ as 'a process whereby all parties with a stake in a specific offence come together to resolve collectively how to deal with the aftermath of the offence and its implications for the future.' ${ }^{54}$ Conceived as such, the RJ process involves five reciprocally linked key features, put forward by Van Ness and Heetderks Strong. ${ }^{55}$ Three of these elements relate to the restorative process, namely (1) victim-offender encounter; (2) offender's acknowledgement of responsibility and apology; (3) collaborative conflict-resolution approach. The other two elements, notably (4) healing and reconciliation of victims and communities; (5) symbolic reparation and material compensation are tied to outcomes of such process. The typical restorative process consists of an encounter (circles, conferencing, and mediation), ${ }^{56}$ which involve a face-to-face meeting with a victim, an offender, their respective supporters and often community members, as representatives of the community's interest. ${ }^{57}$ However, first and foremost, prior to the beginning of the RJ procedure, it is imperative for the offender to admit his/her guilt. Once the offender does so, the restorative procedure can start. The victim-offender meeting aims to encourage dialogue and negotiation

Andrew Ashworth, 'Some Doubts About Restorative Justice', 4 Criminal Law Forum (1993) 277-299; Erik Luna, 'Punishment Theory, Holism, and the Procedural Conception of Restorative Justice', Utah Law Review (2003) 205-302, pp. 227-228. Jo-Anne Wemmers and Katie Cyr, 'Victims' Perspectives on Restorative Justice: How Much Involvement Are Victims Looking For?' 11 International Review of Victimology (2004) 259-274, p. 261; Dorothy Vaandering, 'A Faithful Compass: Rethinking the Term Restorative Justice to Find Clarity', 14 Contemporary Justice Review (2011) 307-328.

Jane J. Bolitho, 'Restorative Justice: The Ideals and Realities of Conferencing for Young People', 20 Critical Criminology (2012) 61-78, p. 76.

Patrick Gerkin, John Walsh, Joseph Kuilema and Ian Borton, 'Implementing Restorative Justice Under the Retributive Paradigm: A Pilot Program Case Study', 7 SAGE Open (2017) 1-10; Wemmers and Cyr, supra note 48; McGonigle Leyh, supra note 10, p. 54.

Tony F. Marshall, 'The Evolution of Restorative Justice in Britain', 4 European Journal on Criminal Policy and Research (1996) 21-43, p. 37.

55 Van Ness and Heetderks Strong, supra note 14; Van Ness, supra note 14.

56 Paul McCold, 'The Recent History of Restorative Justice: Mediation, Circles, And Conferencing', in Dennis Sullivan and Larry Tifft (eds), Handbook of Restorative Justice (Routledge, London, 2008), p. 23. Retributive Components Affects the Acceptability of Restorative Justice Procedures', 19 Social Justice Research (2006) 395-432, p. 396. 
between victims and offenders, since the victim has the chance to explain to what extent the criminal conduct harmed her/him, while the offender has the opportunity to acknowledge the consequences of the harm s/he provoked, s/ he sympathises and sincerely apologises to the victim. ${ }^{58}$ This meeting leads to a collaborative conflict-resolution approach that lies at the heart of $\mathrm{RJ}$ practice as it is concerned with negotiating the settlement of the case. ${ }^{59}$ This negotiated process places victims in an active problem-solving role, as they work together with offenders to reach an agreement on how to overturn the harm originated by the criminal conduct. ${ }^{60}$ Victims and communities' involvement as decision-makers at this stage of the process is crucial because redress cannot be accomplished without the input from those who have suffered the most from the crime. ${ }^{61}$ The outcome of the restorative process is an agreement between the parties on the appropriate terms of compensation to redress the wrongdoing and "heal individuals, communities, and even nations after harm." ${ }^{\text {" } 2 ~ I n ~}$ this kind of agreement, the offender offers as material restitution monetary compensation or some services that they can provide to victims, ${ }^{63}$ but, when material restoration can be unable to undo the effects of the crime, the outcome of this negotiated process should include a symbolic redress seeking to restore the psychological losses and dignity of individuals and communities. ${ }^{64}$

\section{Problematic Positioning of Restorative Practices within the ICC Process}

There is a conceptual difficulty that the restorative mechanisms have to face when entering the international criminal procedure, as it is unclear whether and to what extent the ICC figures its legal proceeding as a practice of RJ as outlined above. The ICC's Strategy and Revised Strategy, which is the primary

58 Ibid.; Moffett, supra note 24, p. 42; Garbett, supra note 24, p. 44.

59 Mark S. Umbreit, Robert B Coates and Boris Kalanj, Victim Meets Offender: The Impact of Restorative Justice and Mediation (Lynne Rienner Publishers, San Francisco, CA, 1994), p. 4.

6o Miriam J. Aukerman, 'Extraordinary Evil, Ordinary Crime: A Framework for Understanding Transitional Justice', 15 Harvard Human Rights Journal (2002) 77.

$61 \quad$ Gordon Bazemore and Sandra O'Brien, 'The Quest for A Restorative Justice Model of Rehabilitation: Theory-For-Practice and Practice-For-Theory', in Lode Walgrave (ed.), Restorative Justice and the Law (Willan Publishing, Cullompton, 2002), p. 43.

62 Kathrine S. Van Wormer, and Lorenn Walker, 'Preface', in Kathrine S. Van Wormer and Lorenn Walker (eds), Restorative Justice Today: Practical Applications (Sage, Thousand Oaks, CA, 2013), p. Xv.

63 Moffett, supra note 24, p. 42; Gromet and Darley, supra note 53, p. 396.

64 Umbreit, Coates and Kalanj, supra note 55, p. 2. 
articulation of the ICC's approach to its victims' mandate, recognised RJ principles, ${ }^{65}$ but failed to integrate them into the modalities of participation and reparation for victims. It is critical to point out that the ICC does not employ central practices of RJ, like mediation, circles and conferencing, which bring victims and offenders together in face-to-face meetings to determine how to fix the harm caused by the wrongdoing in question. ${ }^{66}$

Questions concerning the positioning of restorative mechanisms within international criminal justice should be answered looking at the specific context within which they are used. Practices of RJ have been developed mainly against the background of Westerner democratic societies and their application mainly addresses situations involving first-time offenders, low-level crime and juveniles. ${ }^{67}$ Quite the opposite, international criminal justice is a product of discontinuity, of upheaval and political rupture. ${ }^{68}$ It would be fallacious to ignore the contrasting histories, assumptions and paradigms of domestic and international criminal justice systems, while assessing whether the ICC's justice approach is effectively structured to mete out restorative practices. Unlike domestic crime, international crimes consist of mass atrocities on a scale incomprehensible to those who have not experienced them, causing suffering and mental trauma to victims, but also to those who simply witnessed these events. ${ }^{69}$ International crimes often occur in situations of civil conflict that set community against community ${ }^{70}$, involving, therefore, a wide number of victims and large-scale participation of perpetrators as well. ${ }^{71}$ Victims suffer particularly serious violence, not just at the individual level, but also members of a given community are affected. In fact, the scale of the violence often targets communities on ethnic, political, religious, ideological or economic grounds, in order to destabilise and eventually cause the disintegration of the community not simply physically, but also in terms of its identity. ${ }^{72}$ In this background

\footnotetext{
65 See section 2 of this article.

66 McCold, supra note 52, p. 24.

67 Heikkilä, supra note 18, p. 37; Kerry Clamp and Jonathan Doak, 'More Than Words: Restorative Justice Concepts in Transitional Justice Settings', 12 International Criminal Law Review (2012) 339-36o, p. 346. David J. Luban, 'Fairness to Rightness: Jurisdiction, Legality, and the Legitimacy of International Criminal Law', Georgetown Law Faculty Working Papers (2008) 1-26, p. 8.

69 Moffett, supra note 24, p.12.

$70 \quad$ Paolina Massidda, 'Retributive and Restorative Justice for Victims and Reconciliation: Considerations on the Lubanga Case before the ICC', 1 Peace Processes Online Review (2015) $1-24$, p. 4.

71 Moffett, supra note 24, p. 10.

72 Rauschenbach and Scalia supra note 43, p. $45^{\circ}$.
} 
marked by dysfunctional institutions, serious disruptions of the judicial system and traumatised populations, the ICC is confronted with transitions from conflict to peace, from authoritarianism to a form of democracy and from the dearth of public trust in the State's capacity to the restoration of security, peace and human rights protection. ${ }^{73}$ These core aspects of post-conflict justice situations, which are mainly absent in the domestic realm of criminal justice, pose a challenge to the successful implementation of restorative practices into cases of gross violations of human rights and other serious acts of mass violence and mass victimisation, amounting to international crimes.

The following analysis seeks to assess the extent to which the proceedings before the ICC can deliver a restorative process and whether this process has contributed towards restoration, reparation and healing for victims. It does so by framing the analysis around the five key elements of the RJ practice, as described in the previous section.

\subsection{The Voluntary Victim-Offender Meeting}

The RJ process provides an opportunity for the voluntary meeting between victims and offenders, in which victims are able to ask clarifications and questions, informally express their feelings and emotions, while defendants accept and acknowledge their guilt or, at least, the wrongness of their acts. ${ }^{74}$ Through the expression of emotions, both victims and offenders open up a forum for discussion, which addresses the offence, unsolved and, perhaps, undiscovered emotional consequences of the wrongdoing and eventually develops a narrative for the healing of victims and community at large. ${ }^{75}$ Victims and offenders provide an account of the crime through the lens of a subjective narrative, using an emotional language, instead of the rational legal language. ${ }^{76}$ However, this kind of meetings falls short of the symbolic element of a public trial, as victim-offender dialogue is not mediated through formal legal rules. Such encounters are not concerned with producing legal evidence that a crime occurred, they rather seek to reach a 'mutually satisfactory written restitution agreement 77 between private participants. It is difficult to reconcile

$73 \quad$ Massidda, supra note 66, p. 5 .

74 Brianne McGonigle Leyh, 'Victim-Oriented Measures at International Criminal Institutions: Participation and its Pitfalls', 12 International Criminal Law Review (2012) 375408, p. 380 .

$75 \quad$ Clamp and Doak, supra note 63, p. 354.

76 Claire Garbett, 'The International Criminal Court and Restorative Justice: Victims, Participation and the Processes of Justice', 5 Restorative Justice (2017) 198-220, p. 204. 
these specific features of the voluntary-based encounter with the nature of the trials at the ICC, which are a much more public affair, normatively built as an adversarial contest, constrained by rules of evidence, due process and associated rights. Through the application of evidential rules, the adversarial format of the proceeding enables the judges to identify the central action in the alleged crime; to make empirical connections among evidential elements based on that storyline; and then to interpret and evaluate those connections for consistency, completeness and their collective implications for the central action. ${ }^{78}$

Most significantly, the ICC's Trial Chambers have limited the opportunities for a direct victim-offender encounter to take place, as very few victims have appeared in person in proceedings before the ICC. Common legal representation (CLR) has become a settled feature at the ICC, despite neither the Rome Statute nor the RPE considered it as mandatory. In the Prosecutor v. Thomas Lubanga Dyilo (Lubanga), the Trial Chamber I decided that victims' views and concerns should have been presented through a joint presentation of views and concerns by joint legal representatives. ${ }^{79}$ The Chambers' prerogative of setting groups of victims under legal teams has been confirmed in the Prosecutor v. Jean-Pierre Bemba Gombo ${ }^{80}$ (Bemba) and Prosecutor v. Germain Katanga and Mathieu Ngudjolo Chui ${ }^{81}$ (Katanga and Chui). It can be said that the CLR has the task of condensing victims' personal interests into 'generalisable interests. ${ }^{\prime 2}$ In practice, the CLR enjoys considerable discretion, because, in drawing the victims' interests, the representative filters, weighs and selects the diverging personal interests of the victims. This evaluation risks damaging some of the interests of individual victims, because of the diversity of interests

78 W. Lance Bennet and Martha Feldman, Reconstructing Reality in the Courtroom (Rutgers University Press, New Brunswick, NJ, 1981), p. 67.

79 ICC, Prosecutor v. Thomas Lubanga Dyilo, Case No. ICC-01/04-01/o6, Trial Chamber I, Decision on Victims' Participation, 18 January 2008, para. 116.

$80 \quad$ ICC, Prosecutor v. Jean-Pierre Bemba Gombo, Case No. ICC-o1/o5-o1/o8, Trial Chamber III, Decision on common legal representation of victims for the purpose of trial, 11 November 2010, para. 15. See also ICC, Prosecutor v. Jean-Pierre Bemba Gombo, Case No. ICC-01/05-01/08, Trial Chamber III, Corrigendum to Decision on the participation of victims in the trial and on 86 applications by victims to participate in the proceedings, 12 July 2010, para. 27.

81 ICC, Prosecutor v. Germain Katanga and Mathieu Ngudjolo Chui, Case No. ICC-o1/o4-o1/o7, Trial Chamber II, Order on the organisation of common legal representation of victims, 22 July 2009, paras 10-11.

$82 \quad$ Sara Kendall and Sarah Nouwen, 'Representational Practices at the International Criminal Court: The Gap between Juridified and Abstract Victimhood', 76 Law and Contemporary Problems (2013) 235-262, p. 25 o. 
that CLR represents, which sometimes may be paradoxically in conflict with each other. Latour referred to CLR as a 'mediator', rather than an 'intermediary'. The difference is that, while intermediaries merely channel views, mediators 'transform, translate distort, and modify that meaning of the elements they are supposed to carry. 83

The CLR changes drastically the nature of the role of victims within the proceedings before the ICC, because it contributes to developing the idea of an 'abstract collectivity' or, better, an abstract concept of victimhood. The participation through the CLR, which merges the interests and views of the individual victim within thousands of views of a broad number of victims, does not enhance an effective victims' participation. ${ }^{84}$ This mode of operation of the CLR conflicts with the emerging victims' role as active participants, sustained by RJ practices that supposedly prioritise direct participation in the process of all parties involved in the offence.

\subsection{Offender's Acknowledgement of Responsibility and Apology}

As explained above, the offender has to acknowledge his/her responsibility before the restorative process gets underway. The first step of the restorative process is contingent on the degree to which offenders are genuinely sorry for what they have done and can communicate their remorse effectively. ${ }^{85}$ The process of acknowledging responsibility entails, first, the offender's realisation of the full measure of his/her wrongdoing, as s/he must sincerely feel guilty, rather than formally admit his/her guilt. After acknowledging their culpability, defendants must apologise for their conduct, by providing an explicit manifestation and declaration of repentance and, lastly, they must express willingness to undertake steps to expiate their guilt. ${ }^{86}$

However, in the experience of international criminal justice institutions, the expression of a fully accomplished acknowledgement of guilty and sincere apology is rather unlikely to occur. The case law of the ICTY and ICTR shows that in only a few cases have defendants admitted their guilt and expressed

83 Bruno Latour, Reassembling the Social: An Introduction to Actor-Network-Theory (Oxford University Press, Oxford, 2005), p. 39.

84 Anni Pues, 'A Victim's Right to a Fair Trial at the International Criminal Court? Reflections on Article 68(3)', 13Journal of International Criminal Justice (2015) 951-972, p. 963.

85 Kathleen Daly, 'The Limits of Restorative Justice', p. 10, http://citeseerx.ist.psu.edu/ viewdoc/download?doi=10.1.1.595.9278\&rep=rep1\&type=pdf, accessed 15 July 2020.

86 Stephen P. Garvey, 'Restorative Justice, Punishment, And Atonement', Utah Law Review (2003) 303-317, p. 313. 
profound regret and convincingly apologised for their wrongdoing. ${ }^{87} \mathrm{~A}$ very common occurrence, instead, is the expression of what can be considered an insincere acknowledgement of responsibility. This is due to the practice of accepting statements of apology as a mitigating factor if they include expressions of sincere remorse for wrongdoing. ${ }^{88}$ The jurisprudence of the ICTY has given an extremely broad interpretation of the legal definition of sincere remorse as a mitigating factor. In a few cases, a sincere expression of remorse did not require the admission of criminal responsibility or guilt, but only the defendant's acceptance of some measure of moral blameworthiness for personal wrongdoing. ${ }^{89}$ In other cases, the judges accepted as mitigating circumstances the expressions of remorse made by defendants who maintained their innocence. ${ }^{90}$ Lastly, another strand of decisions by the ICTY and ICTR held that simple expressions of sympathy, compassion or sorrow, which do not amount to remorse as such, ${ }^{91}$ are sufficient to be qualified as mitigating

87 ICTR, Prosecutor v. Georges Ruggiu, Case No. ICTR-97-32-I, Trial Chamber I, Judgment and Sentence, 1 June 200o, paras 69-72; ICTY, Prosecutor v. Tihomir Blaškić, Case No. IT-95-14-T, Trial Chamber, Judgment, 3 March 200o, para. 775; ICтY, Prosecutor v. Dražen Erdemović, Case No. IT-96-22-T, Trial Chamber, Sentencing Judgment, 29 November 1996, paras 96-98; ICTR, Prosecutor v. Omar Serushago, Case No. ICTR-98-39-S, Trial Chamber I, 5 February 1999, paras 40-41.

ICTY, Prosecutor v. Drazen Erdemović, Case No. IT-96-22-Tbis, Trial Chamber, Sentencing Judgment II, 5 March 1998, para. 16(iii); ICTY, Prosecutor v. Stevan Todorović, Case No. IT-95-9/1-S, Trial Chamber, Sentencing Judgment, 31 July 20o1, para. 89; ICTY, Prosecutor v. Milan Simić, Case No. IT-95-9/2-S, Trial Chamber II, Sentencing Judgment, 17 October 2002, para. 92; ICTY, Prosecutor v. Dragan Obrenović, Case No. IT-02-6o/2-S, Trial Chamber I Section A, Sentencing Judgment, 10 December 2003, para. 121; ICTY, Prosecutor v. Miroslav Kvočka et al., Case No. IT-98-30/1-A, Appeals Chamber, Appeal Judgment, 28 February 2005, para. 715; ICTY, Prosecutor v. Tihomir Blaškić, Case No. IT95-14-A, Appeals Chamber, Appeal Judgment, 29 July 2004, paras 678, 696, 705; ICTR, Prosecutor v. Omar Serushago, Case No. ICTR-98-39-S, Appeals Chamber, Sentencing Appeal Judgment, 6 April 200o, para. 39; ICTY, Prosecutor v. Stanislav Galić, Case No. IT-98-29-T, Trial Chamber I, Trial Judgment, 5 December 2003, para. 759; ICTY, Prosecutor v. Dario Kordić and Mario Čerkez, Case No. IT-95-14/2-A, Appeals Chamber, Appeal Judgment, 17 December 2004, para. 1073; ICTY, Prosecutor v. Radislav Krstić, Case No: IT98-33-A, Appeals Chamber, Appeal Judgment, 19 April 2004, para. 713.

89 ICTY, Prosecutor v. Mitar Vasiljević, Case No.IT-98-32-A, Appeals Chamber, Appeal Judgment, 25 February 2004, para. 177.

90 ICTY, Prosecutor v. Tihomir Blaškić, Case No. Iт-95-14-A, Trial Chamber, Trial Judgment, 3 March 20oo, para. 775; ICTY, Prosecutor v. Dragoljub Kunarac et al., Case No. IT-96-23-T\& IT-96-23/1-T, Trial Chamber, Trial Judgment, 22 February 200, para. 869; ICTY, Prosecutor v. Zejnil Delalić et al., Case No. IT-96-21-T, Trial Chamber, Trial Judgment, 16 November 1998, para. 1279.

91 The Oxford English Dictionary defines remorse as "a feeling of compunction, or of deep regret and repentance, for a sin or wrong committed". 
circumstances ${ }^{92}$ Indeed, granting discounts for remorse and apology creates a strong incentive to deceive.

A paradigmatic example of this phenomenon is the case of the Prosecutor v. Biljana Plavšić. During the trial, Mrs. Plavšić pleaded guilty and released a statement in which she accepted her responsibility and expressed her remorse fully and unconditionally, Mrs. Plavšić hopes to offer some consolation to the innocent victims - Muslim, Croat and Serb - of the war in Bosnia and Herzegovina. ${ }^{93}$ The ICTY, in the sentencing judgment, acknowledged that this step by Mrs. Plavšić was 'undertaken under circumstances requiring considerable courage' and it represented 'an unprecedented contribution to the establishment of truth and a significant effort toward the advancement of reconciliation. ${ }^{94}$ The expression of remorse given in her guilty plea allowed Mrs. Plavšić to receive a mild judgment, since the Court dropped the charge of genocide against her. However, several years later she retracted her statement of remorse, explicitly stating she still felt she had done nothing wrong. ${ }^{95}$

In the Prosecutor v. Radovan Karadžić, the defendant's statements appeared calculated, carefully scripted and exactly tailored in order to receive a milder sentence. In a Final Brief, the defendant:

expresses his deep regret and sympathy to the victims (...) and to their families. Regardless of the issue of his individual criminal responsibility for

ICTY, Prosecutor v. Pavle Strugar, Case No. Iт-о1-42-A, Appeals Chamber, Judgment, 17 July 2008, paras 366; ICTY, Prosecutor v. Radoslav Brđanin, Case No. IT-99-36-T, Trial Chamber II, Trial Judgment, 1 September 2004, para. 1139; ICTY, Prosecutor v. Naser Orić, Case No. IT-03-68-T, Trial Chamber II, Trial Judgment, 3o June 2006, para. 752; ICTY, Prosecutor v. Milomir Stakić, Case No. IT-97-24-T, Trial Chamber II, Trial Judgment, 31 July 2003, para. 922; ICTR, Prosecutor v. Jean-Paul Akayesu, Case No. ICTR96-4-T, Trial Chamber I, Trial Judgment, 2 September 1998 para. 45; ICTR, Prosecutor v. Alfred Musema, Case No. ICTR-96-13-A, Trial Chamber I, Trial Judgment, para. 1005; ICTR, Prosecutor v. Alfred Musema, Case No. ICTR-96-13-A, Appeals Chamber, Appeal Judgment, 16 November 2001 para. 396.

93 ICTy Press Release, 'Statement on Behalf of Biljana Plavšić / Statement by Robert Pavich, Lead Counsel for Biljana Plavšić (PIs/697e), 2 October 2002.

94 ICTY, Prosecutor v. Biljana Plavšić, Case No. Iт-oo-39 \& 40/1, Trial Chamber, Sentencing Judgment, 27 February 2003, para. 67.

95 Jelena Subotić, 'The Cruelty of False Remorse: Biljana Plavšić at the Hague', 36 Southeastern Europe (2012) 39-59, p. 48; Daniel Uggelberg Goldberg, Bosnian war criminal: "I did nothing wrong”, Vi Magazine, 26 January 2009, https://www.thelocal.se/20090126/17162, accessed 16 July 2020; Ian Traynor, 'Leading Bosnian Serb war criminal released from Swedish prison', The Guardian, 27 October 20o9, https://www.theguardian.com/ world/2009/oct/27/bosnian-serb-war-criminal-freed, accessed 16 July 2020. 
those crimes (emphasis added), he understands that as President of Republika Srpska, he bears moral responsibility for any crimes committed by citizens and forces of Republika Srpska. ${ }^{96}$

With this statement, Mr. Karadžić apologised to the victims and expressed his regret and sympathy, but he did not admit his criminal responsibility or guilt. He only acknowledged he had moral blameworthiness for the conducts perpetrated by the Republika Srpska citizens, rather than for his actions. This is inconsistent with the restorative acknowledgement of responsibility and apology process, which holds that the perpetrator has to acknowledge his/her culpability and then ask for forgiveness to the victims. In the RJ mechanisms, acknowledgement of responsibility and apology require sincerity and authenticity as the first step towards reconciliation. Conversely, the above-described cases revealed a remarkable gap between the dynamics of the trial in the tribunals' everyday work and the restorative practices, as the offenders failed to turn the corner from formal acknowledgement of their responsibility to a genuine experience of it.

The difficulty in achieving a declaration of guilt and a sincere apology suggests that the RJ might appear less than restorative. The level of restoration includes the degree to which the offenders are remorseful, aware of the impact of the crime on the victim and spontaneously apologetic to the victim. ${ }^{97}$ The lack of a fully accomplished apology jeopardises the restoration of the process that should emerge in the relationship between the victim and the offender and requires a degree of empathic concern and perspective-talking. ${ }^{98}$

\subsection{Collaborative Conflict-Resolution Approach}

The collaborative conflict-resolution approach aims to achieve an agreement between the parties involved in the process, with regard to "what should be done to achieve both material and emotional restoration.'99 This approach does not provide any method of adjudication because restorative practices are participatory and consensually based, ${ }^{100}$ meaning that there is no judge, only

96 ICTY, Prosecutor v. Radovan Karadžić, Case No. IT-95-5/1, Trial Chamber, Public Redacted Version of Judgment Issued on 24 March 2016 Volume I of IV, 24 March 2016, para. 6059.

97 Daly, supra note 81, p. 5 .

98 Idem., p. 6.

99 Heather Strang, 'Conferencing and Victims', in Estelle Zinsstag and Inge Vanfraechem (eds), Conferencing and Restorative Justice: International Practices and Perspectives (Oxford University Press, Oxford, 2012), p. 85. 
a facilitator, whose main function is to ensure that the victim-offender dialogue remains within the boundaries of mutual respect. ${ }^{101}$ That said, it does not mean that the restorative process does not hold the offenders accountable, but the standard of restorative accountability needs offenders to acknowledge their culpability and willingness to amend for their wrongdoing. ${ }^{102}$

In the conflict-resolution approach there should be no place for punitive measures, such as prison sentences. ${ }^{103}$ Punishment is not imposed on the offender; conversely, amends arise from the accused themselves who accept the burden and recognise it as the price to be paid to expiate their guilt.104 This view clashes with the Preamble of the Rome Statute, which, by affirming that 'the most serious crimes of concern to the international community as a whole must not go unpunished ..., ${ }^{105}$ demands the ICC to pursue justice through adjudication and punishment and not by means of an agreement made between victims and offenders. More specifically, the ICC Statute does not envisage any role for victims in the decision-making and sentencing process. The decision on the guilt or innocence of the defendant is issued through judgment by a Trial Chamber, ${ }^{106}$ and, in case of a conviction, the determination of the appropriate sentence to be imposed on the convicted one is still a task of the Trial Chamber. ${ }^{107}$ The exclusion of victims from the decision-making process is confirmed by the fact that they are not allowed to present during the trial those evidence relevant to the Trial Chamber's decision. In Lubanga and Bemba, the victims' expression of views and concerns is the equivalent of presenting submissions, which can assist the Chamber in its approach to the evidence in the case, but do not form part of the trial evidence. ${ }^{108}$

\footnotetext{
101 Garvey, supra note 82, p. 314.

102 Aukerman, supra note 56, p. 84.

103 John Braithwaite, 'Restorative Justice', In Michael Tonry (ed.), The Handbook of Crime and Punishment (Oxford University Press, Oxford, 2000), pp. 113-147.

104 Garvey, supra note 82, p. 314.

105 ICC, Rome Statute, Preamble.

$106 \quad$ ICC, Rome Statute, Article 74.

$107 \quad$ Ibid., Article 76.

108 ICC, Prosecutor v. Jean-Pierre Bemba Gombo, Case No. ICC-01/05-01/o8, Trial Chamber III, Decision on the supplemented applications by the legal representatives of victims to present evidence and the views and concerns of victims, 22 February 2012, para. 19; ICC, Prosecutor v. Thomas Lubanga Dyilo, Case No. ICC-01/04-01/o6, Trial Chamber I, Decision on the request by victims a/ 0225/o6, a/o229/o6 and a/o27o/o7 to express their views and concerns in person and to present evidence during the trial, Public Annex, o9 July 2009, para. 25 .
} 
While a pure conflict-resolution approach seems reasonable for non-serious offences committed by young offenders, ${ }^{109}$ moving beyond the retributive-focused paradigm of international criminal justice does not properly fit the seriousness and heinousness of the large-scale violence perpetrated against civilians and communities. In the adversarial arena of the ICC, the visible punishment of perpetrators seems more likely to serve the interests of justice.

\subsection{The Healing and Reconciliation Outcome}

The extent of the burgeoning body of literature on the sufferings of victims brought about through mass conflicts illustrates that victims experience a high tendency to develop depression and anxiety arising from the internalisation of negative feelings, such as self-blame, outrage, alienation and exclusion during any subsequent legal proceedings. ${ }^{110}$ Victims can also suffer from the fragmentation of their community and social culture of segregation. In war-torn and impoverished societies, the long-term employment of coping mechanisms can endanger victims' health. Pena and Carayon have expressed their strong belief that the ICC can deliver RJ to victims through their participation at trial, which per se can 'be an important factor in their healing and rehabilitation.'111

The possibility of healing victims and affected societies through their participation at the ICC has been also discussed by the Court. In the Strategy, the ICC acknowledged the importance of understanding the devastating effect that crimes can have on victims and, therefore, recognised that a positive engagement with victims can contribute to their healing process. ${ }^{112}$ This view was confirmed in the Revised Strategy, wherein the ICc holds that victims' participation in the justice process is one step on the road to healing, not only for individuals, but for affected societies as well. ${ }^{113}$ The recognition of the dignity of victims as human beings ${ }^{114}$ and of the need to ensure that the interaction between victims and the ICC is positive and beneficial, ${ }^{115}$ is largely consistent

\footnotetext{
109 Andrew Ashworth, 'Victims' Rights, Defendants' Rights and Criminal Procedure', in Adam Crawford and Jo Goodey (eds), Integrating a Victim Perspective within Criminal Justice: International Debates (Routledge, London, 200o), pp. 193-194. Jonathan Doak, 'The Therapeutic Dimension of Transitional Justice: Emotional Repair and Victim Satisfaction in International Trials and Truth Commissions', 11 International Criminal Law Review (2011) 263-298, p. 265. See Patrick Bracken, Trauma: Cultural Meaning and Philosophy (Whurr Publishers, London, 2002).

$111 \quad$ Pena and Carayon, supra note 4, p. 522.

112 Report of The Court on The Strategy in Relation to Victims, supra note 47, para. 2.

113 Ibid., paras 2, 10.

114 Ibid., para. 6.

115 Ibid., para. 15 .
} 
with the compelling concept of RJ. However, neither the Strategy, nor the Revised Strategy clarified how the justice process can effectively heal the individual and reunite splintered communities, given that, apart from setting objectives and principles, they do not develop detailed approaches to victims' participation to be applied in the proceedings before the ICC.

At the level of individuals, the contention that there is a connection between victims' engagement in international criminal proceedings and their restoration is unverified so far, as little has been written about the cathartic and therapeutic experience of victims expressing their views and concerns before the ICc. ${ }^{116}$ The only study to date on the experience of victims as participants in international criminal trials and their views following such participation was conducted in the context of the trial of Kaing Guek Eav, better known as the Duch case, before the Extraordinary Chambers in the Courts of Cambodia (ECCC). ${ }^{117}$ The study interviewed victims participants to examine how they perceived the participation in the trial, the work of the ECCC, and how, if at all, it had affected them. ${ }^{118}$ Generally, victims viewed the experience of participating and providing testimony positively, since 'the trial made them feel stronger mentally and increased their hopefulness about the future.'119 However, victims, when asked specifically whether or not the trial had an impact on forgiveness, reconciliation and mental health, were more negative compared to the Cambodian population. Regarding forgiveness and reconciliation, victims-participants were more negative than the general population about the trustworthiness of the defendant's apology and their readiness to reconcile with him after the trial. In more general terms, civil parties were more negative about the ECCC's contribution to reconciliation, rebuilding trust in Cambodia and bringing justice to victims. ${ }^{120}$ Considering the impact on mental health, the expected restorative effects of participation were not observed, as none of the victims described any cathartic or healing effect. ${ }^{121}$ Victims were also less positive about the ability of the trial to help them to accept the loss of loved ones and come to terms with the

116 Michael L. Perlin, 'The Ladder of the Law Has No Top and No Bottom: How Therapeutic Jurisprudence Can Give Life to International Human Rights', 37 International Journal of Law and Psychiatry (2014) 535-542; Dejo Olowu, 'Therapeutic Jurisprudence: An Inquiry into Its Significance for International Criminal Justice', 76 Revista Juridica Universidad de Puerto Rico (2007) 129-15o, p. 13 o.

117 Phuong N. Pham, Patrick Vinck, Mychelle Balthazard, Judith Strasser and Chariya Om, 'Victim Participation and the Trial of Duch at the Extraordinary Chambers in the Courts of Cambodia', 3Journal of Human Rights Practice (2011) 264-287.

$118 \quad$ Ibid., p. 280.

$119 \quad$ Ibid., pp. 281, 284.

$120 \quad$ Ibid., pp. 282-283.

121 Ibid., p. 284. 
past. ${ }^{122}$ Victims' participation in trials at the eccc turned out to be of little help in contributing to the recovery of highly distressed victims. This can suggest that the healing effect of the ECCC's proceedings for victims is not mandatory or a regular outcome, but, on the contrary, those effects are strictly individual and subject to variables that are difficult to foresee in advance. ${ }^{123}$ The context in which the ECCC operates, characterised by heinous and widespread crimes and an extremely violent social and institutional background where such atrocities occur, allows the building of a nexus with the participation of victims in proceedings before the ICC. The finding of this study casts doubts on the capacity of the ICC to effectively bring about therapeutic effects and beneficial outcomes in order to heal the harm and suffering experienced by victims.

At the collective level, it is even more difficult to ascertain the extent to which the participation of the individual victim can contribute to the reconciliation and restoration of society. ${ }^{124}$ In the aftermath of mass violence, societies are characterised by complex politicised issues and, at a basic level, prosecution can effectively remove public figures whose presence impedes reconciliation, but it is still questionable whether and how the ICC can undertake the ambitious task of providing social catharsis. The capacity of the RJ process of transforming the relationship between victims, perpetrators and society requires a close interaction between people responsible for such gross violations of human rights and their victims. Studies showed that the ICTY and ICTR, instead of being vehicles for public catharsis and promoting reconciliation, in some cases deepened the contrasts within ethnically divided communities and confirmed existing biases. Akhavan reported that each Yugoslav ethnic group thought that the tribunal favoured the other and was biased against it. ${ }^{25}$ Meernik observed that the effect of trials at the ICTY was quite the opposite of reconciliation for destabilised communities. In his study of the relationship between the trials at the ICTY and reconciliation, the author found that ' $[\mathrm{m}]$ ore often than not, ethnic groups responded with increases hostility toward one another after an arrest or judgment.'126

\footnotetext{
$122 \quad$ Ibid., p. 282.

123 Solange Mouthaan, 'Victims Participation at the ICC for Victims of Gender-Based Crimes: A Conflict of Interest?' 21 Cardoso Journal of International and Comparative Law (20122013) 619-652, p. 648.

124 Vasiliev, supra note 14, p. 65.

125 Payam Akhavan, 'Beyond Impunity: Can International Criminal Justice Prevent Future Atrocities?' 95 The American Journal of International Law (2001) 7-31, pp. 16-17 and 21-22. 126 James Meernik, 'Justice and peace? How the International Criminal Tribunal Affects Societal Peace in Bosnia', 42 Journal of Peace Research (2005) 271-289, p. 287.
} 
Recently, the discussion on the reduction of Lubanga's sentence ${ }^{127}$ has arisen issues concerning the effective contribution to peace and reconciliation of the judicial proceedings at the ICC. Consultations with victims, NGO s, community leaders and activists illustrate that there was major disagreement about the impact on security and reconciliation of Lubanga's possible resettlement in the DRC. Some expressed fear that Lubanga's release from prison could undermine the peace process and destabilise the situation in the Ituri region, by reigniting tension between the communities and fomenting reprisals for the victims. ${ }^{128}$ Others argue that Lubanga's release can contribute to reinforce peace and consolidate reconciliation. ${ }^{129}$ The different reactions to the prospect of Lubanga being freed, which range from frustration and despair by victims to satisfaction by Lubanga's network, demonstrate that, in post-conflict societies, achieving reconciliation by a judicial process is a rather difficult task. In this scenario, the reconciliation and healing in the community dimension through international criminal proceedings are yet to be empirically verified.

\subsection{Material Restitution and Symbolic Reparation}

Restoring victims and the wider community by reparation and compensation is an important key feature of $\mathrm{RJ}$. Along with the more conventional means of material reparation, like proprietary and monetary measures, symbolic redress is widely considered to be a fundamental element of $\mathrm{RJ},{ }^{130}$ particularly in those cases where the harm caused to victims is of moral nature. ${ }^{131}$ In the context of international crimes, material restoration can be unable to undo the effects of serious and traumatic events and rectify the harm caused to victims and societies. ${ }^{132}$ Symbolic redress, therefore, can come into play to contribute to

127 ICC, Prosecutor v. Thomas Lubanga Dyilo, Case No. ICC-01/04-01/o6, Appeals Chamber, Decision on the review concerning reduction of sentence of Mr Thomas Lubanga Dyilo, 22 September 2015.

128 ICC, Prosecutor v. Thomas Lubanga Dyilo, Case No. ICC-01/04-01/o6, Appeals Chamber, Observations of the Vor group of victims on the possible review of Mr Thomas Lubanga Dyilo's sentence, 10 July 2015, paras 11-13.

129 Massidda, supra note 66, p. 21.

$130 \quad$ See Zehr, supra note 37; Howard Zehr and Bill Toews (eds), Critical Issues in Restorative Justice (Criminal Justice Press, Monsey, NY, 2004); Dennis Sullivan and Larry Tifft, Restorative Justice: Healing the Foundations of our Everyday Lives (Willow Tree, Monsey, NY, 2005); Susan Sharpe, 'The Idea of Reparation', in Gerry Johnstone and Daniel Van Ness (eds), Handbook of Restorative Justice (Willan Publishing, London, 2007).

$131 \quad$ Clamp and Doak, supra note 63, p. 351.

132 Naomi Roht-Arriaza, 'Reparations Decisions and Dilemmas', 27 Hastings International and Comparative Law Review (2004) 157-219, p. 159. 
restoring victims' dignity and making it easier for them to cope with multiple losses they suffered. ${ }^{133}$ In this view, the TFV's Strategic Plan held that the concept of reparation is in no way limited to individual monetary or material compensation. It could also include symbolic forms of reparation, which, being focused on providing recognition of the injustices that have occurred, mark a major step towards healing and reconciliation. ${ }^{134}$ In the Prosecutor v. Uhuru Muigai Kenyatta, Judge Eboe-Osuji further develops the concept of symbolic reparation, by observing that the right to reparation for victims should be in step with developments in international law that lay a great store in ensuring that $\mathrm{RJ}$ is delivered to the victims. ${ }^{135}$ In this connection, an element of symbolic redress is satisfaction, which belongs to the stock list of what reparation has been accepted to mean in international law. ${ }^{136}$ The Judge draws on Principle 22 of the Basic Principles and Guidelines on the Right to a Remedy and Reparation for Victims of Gross Violations of International Human Rights Law and Serious Violations of International Humanitarian Law to explain that satisfaction includes: disclosure of the truth, verification of the facts, and a judicial decision restoring the dignity, reputation and rights of victims. ${ }^{137}$ Therefore, the value of satisfaction as a measure of reparation includes, among other things, the right of the victims to have their day in court to settle the truth to the extent possible. ${ }^{138}$ In this vein, if proceedings at the ICC are understood to provide symbolic reparation, they should reasonably comprise both the recovery of facts, which relates to the victims' narration of the truth and harm suffered, and their clarification through the formal acknowledgement by the ICC of victims' experiences in the judgment rendered against the accused.

However, the ICC seems to be ineffective when addressing these features of symbolic redress for victims, as its focus remains on the proof of guilt rather than on truth-finding and acknowledgement of victims' experiences. In Lubanga, the proceeding neither exhaustively recovered the truth of victims' harms through their truth-telling, nor did the outcome of the case adequately acknowledge the victims and their harm. The Trial Chamber limited the potential contribution of victims 'views and concerns' to the construction of the truth of the events under adjudication, because, despite victims' claims,

Mahmoud Cherif Bassiouni, 'International Recognition of Victims' Rights', 6 Human Rights Law Review (2006) 203-279, p. 231.

134 The Trust Fund for Victims, TFV Strategic Plan 2014-2017, August 2014, p. 18.

135 ICC, Prosecutor v. Uhuru Muigai Kenyatta, Case No. ICC-o1/o9-o2/11, Trial Chamber v(B), Dissenting Opinion of Judge Eboe-Osuji, 27 November 2013, para. 61.

136

Ibid.

137 Ibid.

$138 \quad$ Ibid., para. 62 . 
sexual violence was not included in the charges as forming an intrinsic part of the recruitment and use of child soldiers. The Lubanga trial provides an account of the actions of the accused, but it leaves the narrative of victims' harms and experiences in connection with sexual crimes outside the courtroom. Similarly, Lubanga's sentencing judgment established the role and responsibility of the offender for the recruitment of child soldiers, but neither clarified nor validated the experiences of the victims of sexual violence, nor included any consideration on the effects of harms as victims understood and felt them. ${ }^{139}$

In $B e m b a$, the judges failed to substantiate victims' individual experiences, since they instructed victims' legal representatives on the criteria to narrow down the list of 17 victims included in the applications into a shorter list of no more than eight individuals. ${ }^{140}$ The lack of direct participation by victims was exacerbated by the CLR scheme adopted in this case. Only two representatives were present in the courtroom acting on behalf of their assigned victim-participants, ${ }^{141}$ whose views were filtered and eventually lost to the majority of the views. The participation of a chosen few victims fails to create a link among perpetrators, their criminal conducts and all victims, leading to a potential symbolic restoration for only some of them, which is not what $\mathrm{RJ}$ intends to achieve. ${ }^{142}$

Bemba and Lubanga have shown the difficulties met by the ICC in providing a symbolic restorative effect for victims participating in trials. If we follow the principle of symbolic redress as a fundamental element of RJ, the ICC should also function to recover and clarify the truth of the harm and experiences of victims. The proceedings and outcomes of these cases, on the contrary, do not adequately contribute to the full disclosure of the truth. Victims' direct form of participation, their individual experiences and the impact of the harm on their past, present and future lives are constrained to serve the retributive model of justice, focused to prove or refute the guilt of the accused. The narrative constructed in the courtroom has decontextualised, recategorised and re-organised the events. In this way, the Bemba and Lubanga judgments have represented the harmful act perpetrated against victims, but not the harm of

\footnotetext{
139 ICC, Prosecutor v. Thomas Lubanga Dyilo, Case No. ICC-01/04-01/o6, Case Information Sheet.

ICC, Prosecutor v.Jean-Pierre Bemba Gombo, Case No. ICC-o1/o5-01/o8-2027, Trial Chamber III, Second Order Regarding the Application of the Legal Representatives of Victims to Present Evidence and the Views and Concerns of Victims, 21 December 2011, paras 11-12. ICC, Prosecutor v. Jean-Pierre Bemba Gombo, Case No. ICC-01/o5-01/o8-2027, Trial Chamber III, Judgment pursuant to Article 74 of the Statute, 21 March 2016, paras 23-24. 
the act itself experienced by victims. It appears questionable whether the ICC, by excluding several victims from the proceeding, as happened in Bemba, or by prohibiting victims from relating details about sexual violence, as this was not relevant to the charges of the Lubanga case, can live up to the promises of rendering a symbolic redress to victims.

\section{$5 \quad$ Conclusion}

While the scholarly debates on the victim-based provisions of the Rome Statute have been marked by the contention that the ICC leans towards a restorative form of justice, this article has cast doubts on the pertinence of labelling the ICC as an RJ institution. In principle, there is nothing which prevents the ICC from aspiring to the ideals of RJ. Principles of RJ, like granting to victims the opportunity to have their voices heard in the legal process, healing victims, repairing the harms done to them, and reconciliation of affected community, are reflected in the growing importance that participation in proceedings at the ICC plays in achieving justice for victims. However, this article has added to this debate by showing that the ICC does not align to RJ practice and its prioritisation of victims' participation. The bulk of this article was spent on investigating the hurdles faced by the ICC in aligning with the five core elements of RJ practices delivering a restorative process. It has argued that these elements, developed to address juvenile criminality, first-time offenders and low-level crime, are not structured to operate in the particular context of the ICC, which is characterised by grave harm caused to victims and communities by mass atrocity.

The trial-focused process of the ICC reflects divergences from RJ practice. First, it has rarely allowed direct participation by victims, preventing the victims-offenders encounter from taking place. In the adversarial arena of the ICC, dominated by rules of evidence, opportunities for such voluntary-based encounters, where victims enter into dialogue with the offenders to describe the harms that flowed from the wrongdoing, the emotional consequences and the impact upon their lives, are extremely limited. In proceedings at the ICC, where the adversarial duel between the defence lawyers and prosecutor seeks respectively to disprove or prove the offender's guilt, communication flows only through legal representatives speaking on behalf of victim-participants and lawyers representing the accused.

Second, the ICC trial setting displays a further discrepancy from restorative practice requiring the offender to admit his/her liability for the offence. Defendants have mostly been unwilling to admit their liability for the 
offence, instead, they have challenged the legitimacy of the trial process and, even at the point of the conviction, rejected offers to demonstrate or declare remorse. In several cases, the defendant's apology statement was carefully scripted and tailored in order to receive a milder sentence, rather than to acknowledge responsibility and express remorse and apologise to victims. More in general, the recognition that, without the offender's acknowledgement of his/her guilt, the restorative process cannot begin, casts doubts on the understanding that the integration of victims into proceedings marks the shift towards a restorative function for the ICC. When this requirement is missing, victims' participation at the ICC trials can be an effective way to express emotional suffering, but it is not a sufficient element to make the process restorative. It appears reasonable to suggest that conferring an active role in the judicial process to victims is not enough to convert the ICC system into a restorative one.

Third, the collaborative conflict-resolution approach holds the offender responsible, but does not provide any method of adjudication because it is participatory and consensually-based, requiring offenders to acknowledge their culpability and willingness to amend for their wrongdoing. This approach is primarily about reconciliation and reparation, not about the adjudication of guilt or innocence and, therefore, it conflicts with the Preamble of the Rome Statute that urges the ICC to prosecute and punish those responsible for the most heinous crimes. The Statute suggests that, given the seriousness of the crimes that the ICC adjudicates, reparation and restoration without accountability and punishment fall short of justice. Moreover, in the context of the ICC, the chances that the offender volunteers to make up for his/her conduct are minimal.

Fourth, this article has challenged the view that the proceedings before the ICC run a therapeutic process for social catharsis and restore individuals and society as well. The few studies undertaken were mostly small-scale and the empirical research made very limited inquiries into mental health issues of participating victims, nevertheless, they do not form a promising picture. At the level of micro-dynamics, trials did not have a substantial impact on forgiveness and reconciliation for victims, neither expedited any cathartic effect or recovery from any post-traumatic stress or any other clinical condition. On a macro level, the connection between reconciliation and the ICC process is a difficult one to make, since it entails a prior relationship among communities that requires to be resumed, while it is often not possible. The extremely violent social and institutional background where widespread crimes occur makes it almost impossible to rewind events and undo the effects of victimisation on such a profound scale. This arguably brings into question the extent 
to which reconciliation could ever occur at any meaningful level within the current justice mechanisms of the ICC.

Fifth, the extent to which existing normative and structural bases of trials at the ICC could succeed in restoring victims and the wider community by symbolic reparation is rather questionable. Symbolic reparations are more than just responding to victims' basic needs, since they should be received as the recovery of the victims' narration of the truth and harm suffered and their clarification by the formal acknowledgement within the judgment rendered against the accused, in order to provide some real measure of justice to those harmed. In Bemba and Lubanga, the implementation of the modalities of victims' participation at trial in respect of the function to recover and clarify the truth of the harm experienced has shown that the ICC has not significantly contributed to render a symbolic redress to victims. The ICC, rather, produced a very selective account and decontextualisation of past events, which may let down victims, as it has not contributed to unveil the truth of the events and restore the dignity, reputation and rights of victims.

In conclusion, by drawing attention to the problematic nature of thinking about RJ within the context of mass atrocities and gross human rights violation, this article argues for a much greater degree of caution to be used when employing the restorative label in relation to the justice approach of the ICc. The introduction of victims' active participation in proceeding in the ICc legal framework shows significant potential for providing new forms of justice to address and redress the harm suffered by victims; however, the attempt to clarify some of the key concepts underpinning the RJ process underlines the ICC's failure to set out clear parameters of its restorative function. 